\title{
Biomorphological features of varieties Canna $x$ generalis Bailey when introduced under arid conditions
}

\author{
Shohista Samatova*, Lutfullo Yoziev, and Muhayyo Buranova \\ Karshi State University,180013, Kashkadarya region, Uzbekistan
}

\begin{abstract}
The article presents the results of studies of the biomorphological features of cannas in arid conditions. It was found that the varieties differ in the height of shoots and their number, the number of leaves and flowers on the shoots, the number of renewal buds formed by the end of the growing season. On one shoot of the Crozi cannas varieties, 2-4 renewal buds are laid, of which 1-2 shoots develop. All varieties are characterized by: the effect of the size of the 1st assimilating leaf on the total number of leaves is observed only on the first order shoots; an increase in the height of shoots with an increase in their order; a decrease in the number of leaves with an increase in the order of shoots; in the conditions of the Karshi oasis at an elevated air temperature (average tenday values from +26.7 to $+33.4^{\circ} \mathrm{C}$ ) in June-August - there is an increased growth and development of the aboveground part, with a decrease in temperature (to $19.5^{\circ} \mathrm{C}$ ) from the end of September - underground. Keywords: biomorphological, cannas, Canna X generalis Bailey.
\end{abstract}

\section{Introduction}

Karshi oasis is included in the desert zone and is considered one of the driest regions of Uzbekistan. The amount of precipitation usually does not exceed $200 \mathrm{~mm}$ per year. Winters are generally warm, short, with light and unstable snow cover. Spring is short and early. The xerothermal period begins at the end of April. Summer is long, hot, cloudless, dry and dusty. The hottest month is July, sometimes August. The maximum air temperature often reaches $50^{\circ} \mathrm{C}$. There may be days with very severe air droughts, in which the relative humidity of the air during the day drops to $20 \%$. The average number of days with air drought (with relative humidity below 50\%) per year is 40 days. The unfavorable aspects of the summer growing season include an increased degree of dryness: the number of years with strong dry winds in July reaches $40-70 \%$, with very strong dry winds - almost $10 \%$. The average wind speed on days with dry winds reaches $4.2 \mathrm{~m} / \mathrm{s}$. Autumn begins in September: rains begin to fall, the air temperature drops, frosts are possible from the end of October [1,2]. In such conditions, there is a constant need to expand the range of promising floral and ornamental plants for landscaping.

Cannas hybrid - perennial herbaceous polycarpic plants. Their shoots are considered

*Corresponding author: canna_luiza@mail.ru 
monocarpic, developing from renewal buds and completing their development cycle with the formation of inflorescences [3,4]. Shoots die off after fruiting, but the basal areas remain alive and are included in the perennial branched stem formation. The main role in plant nutrition belongs to adventitious roots $[5,6]$.

The shortened axis of the underground part of the shoot - the rhizome - develops horizontally, somewhat obliquely and forms lower scale-like leaves, buds, and adventitious roots. Scaly leaves, located in two rows, die off rather quickly. Buds are laid in the leaf axils of the inflorescence shoot [3,5,6,]. During the growing season, from the buds of rhizome renewal, leaves with elongated sheaths are formed above the ground, which together define the aerial part of the plant - a kind of stem [3]. Long open sheaths wrap around each other and form false stems. According [7] cannas shoots, according to the degree of specialization, belong to the group of strictly generative shoots.

Cannas hybrid (Canna $\mathrm{X}$ generalis Bailey) are resistant to high air temperatures. Features of the anatomy of the leaves allow them to withstand intense insolation and high air temperatures [3]. The lethal temperature for most cannas varieties is $+51-53^{\circ} \mathrm{C}$, and for some $-+54-55^{\circ} \mathrm{C}$. Due to the vigorous consumption of water for evaporation, cannas leaves do not overheat even in the hot season. Their temperature is usually $1.5-2.5^{\circ} \mathrm{C}$ lower than the ambient temperature [8].

The introduction of the hybrid cannas to the Karshi oasis is limited by the dry and hot weather of the spring-summer period. The response to high temperatures and low relative humidity in cannas varieties is primarily reflected in growth and development. Under such conditions, introduced species have weak growth, delay or absence of flowering of the first order shoot. For cannabis varieties cultivated in arid regions, the weather conditions of the initial stage of development of the rhizome cuttings, as well as the period of initiation and formation of reproductive organs, are important. Sufficient development of plants before the onset of hot and dry weather significantly affects the growth, development and decorativeness of the canna. In the conditions of the Karshi oasis, planting rhizome cuttings in the ground at an early date (late March - early April) allows plants to develop sufficiently (up to 4-5 leaves) before the onset of the xerothermal period. In the future, powerful leaves shade the surface of the earth and thereby largely reduce the negative effect of high summer temperature and low relative humidity on the development of shoots of subsequent orders [9].

When studying the features of morphogenesis, depending on the localization of the axillary meristems, it was found that the rate of development and biomorphological characteristics of cannas plants are largely determined by the location of the axillary meristems that form the buds of renewal. To create aligned in height and flowering time of hybrid canna plantations, it is recommended to use rhizome cuttings taken by the buds in the axils of the 4th-5th scale-like leaves, and use the buds from the 1st order shoots only for breeding purposes [10].

The study of biomorphological features and the identification of patterns of morphogenesis of cannas varieties is of interest, primarily in terms of studying the influence on it of the peculiar climatic and weather conditions of the Karshi oasis.

\section{Materials and methods}

The studies were carried out in 2017 in the Karshi oasis of the Republic of Uzbekistan on the basis of the Karshi State University. The soil is old-irrigated oasis, non-saline. By granulometric composition - medium loam. 
The objects of the study were highly decorative cannas varieties of foreign selection: 4 varieties from the Crozi cannas variety type (Crimean Dawns, America, Louise von Ratibor, President) and 4 varieties from the orchid-like cannas variety type (Andenken an Wilgelm Pfitzer, Bengal Tiger, Feuer Vogel), Rosenkranzenzen. The variety was determined according to the works [3,5]

Rhizome cuttings with two well-formed buds (in the axils of the 4-5th scale-like leaves) were planted on April 1 in ridges according to the $35 \times 60 \mathrm{~cm}$ scheme. The soil was cultivated to a depth of $30 \mathrm{~cm}$. Manure $\left(5 \mathrm{~kg} / \mathrm{m}^{2}\right)$ was applied as fertilizer before planting. The cultivation technique (care, loosening the soil, watering) was applied according to the application to Uzbekistan.

To study morphological traits, the experiment included 20 plants from each variety. Studied: plant height $(\mathrm{cm})$; the number of shoots, flowering shoots, flowers per plant, the number of buds formed by the end of the growing season (pcs.) $(n=10)$. Plant height was measured at the end of the growing season. The number of flowers was determined at the end of each shoot flowering. The number of shoots and buds per rhizome was determined by counting at the end of the growing season.

To study the growth and development of underground organs, one variety was selected from each variety type (President and FeuerVogel). For this purpose, 30 identical rhizomatous cuttings (with two well-formed buds) of each variety were planted and the analysis was carried out twice a month (15th and 30th numbers) during the growing season. In each sample, two plants from each variety were examined. At the same time, observations were made on the formation of aboveground organs.

For morphological analysis and schematic representation of the growth of shoots, the methods of P.K. Krasilnikov [11] and T.I. Serebryakova [4].

The obtained biometric data were processed in accordance with generally accepted standard methods of descriptive statistics using the computer programs "STATISTICA 5.5" and "MS EXCEL".

\section{Results and discussion}

In the conditions of the Karshi oasis, the growth of shoots of all cannabis varieties goes on continuously during the growing season and is forcedly interrupted only for the winter.

In total, 17-19 leaves are formed on the canna shoot. When describing, we distinguish the following leaves: scale-like, transitional, assimilating and covering the leaves of the wrapper. The first 6 leaves are considered to be scale-like, the 7-9th leaves are transitional to the assimilating leaves, the 10-16 (18) leaves belong to the aerial part of the shoot and are considered to be assimilating leaves. The cover leaf of the wrap is the very last leaf on the shoot (picture). The development of lateral shoots occurs only in the axils of scaly and transitional leaves.

On one shoot of the Crozi cannas varieties, 2-4 renewal buds are laid, of which 1-2 shoots develop. The buds in the axils of 6-7 scaly leaves are dormant. These buds during winter storage of plants in the overwhelming majority die off, and even with year-round cultivation of plants in a greenhouse, the development of these buds is not observed [12].

In varieties of cannas Crozi, shoots up to IV order are formed during the growing season. 3, less often 4 shoots of I-III orders bloom. By the end of the growing season (due to frost), in the basal part of the shoots of I-III orders, there are renewal buds only in the axils of 5-6 scaly leaves, since the renewal buds formed in the axils of the 4th scaly leaves gave rise to the corresponding shoots. The size of buds formed in the axils of the 4th-5th 
scale-like leaves is larger than in the axils of the 6th scale-like leaves. The largest buds are formed in the axils of 4 and 5 scaly leaves of shoots that have not reached flowering (Table $1)$.

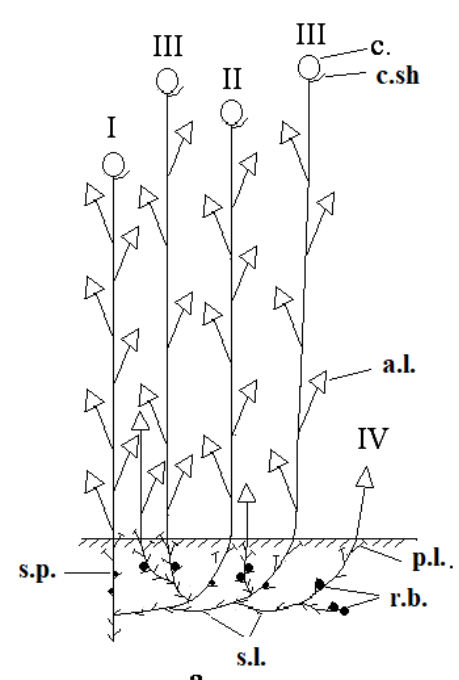

a

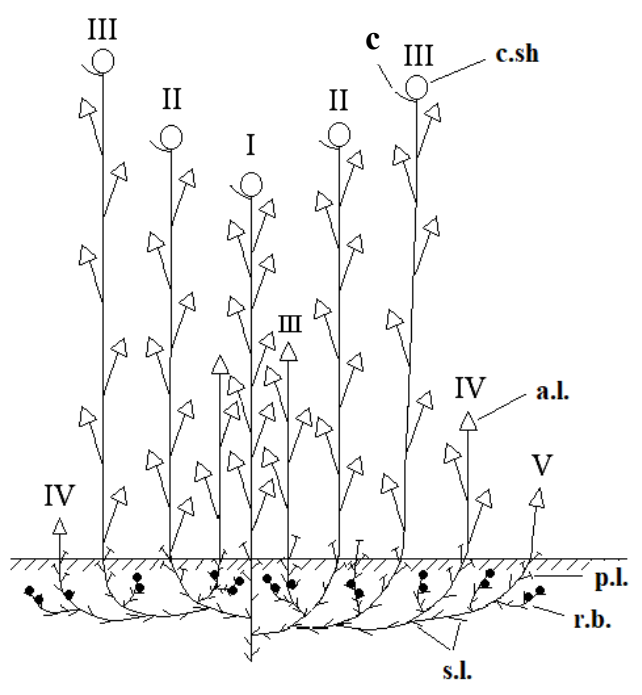

B

Fig. 1. The branching scheme of cannas shoots of different varieties (November, 2017): a) Crozi variety, President variety; b) orchid-like cannas variety, variety Feuer Vogel; a.1 -assimilating leaf; c.sh. cover sheet wrap; r.b.. - reproduction buds (renewal); p.l. - transition sheet; c. - inflorescence; s.p. sleeping kidney; s.l. - scale leaf; I, II, III, IV, V - branching order of shoots.

Table 1. Renal sizes of renewal depending on the position on the shoot and the order of shoots (variety America, 2017)

\begin{tabular}{|c|c|c|c|c|c|c|c|c|}
\hline \multirow{2}{*}{$\begin{array}{c}\text { Branching } \\
\text { order of } \\
\text { shoots }\end{array}$} & \multicolumn{9}{|c|}{ The kidney in the sinus: } \\
\cline { 2 - 9 } & Diameter & Height & Diameter & Height & Diameter & Height & Diameter & Height \\
\hline I & $3,0 \pm 0,06$ & $3,5 \pm 0,09$ & $2,3 \pm 0,15$ & $3,7 \pm 0,09$ & $2,3 \pm 0,2$ & $2,6 \pm 0,2$ & $1,1 \pm 0,1$ & $1,5 \pm 0,1$ \\
\hline II & $2,4 \pm 0,04$ & $4,06 \pm 0,08$ & $3,0 \pm 0,06$ & $4,7 \pm 0,1$ & $3,2 \pm 0,1$ & $4,2 \pm 0,1$ & $1,5 \pm 0,3$ & $3,1 \pm 0,4$ \\
\hline III & $3,5 \pm 0,2$ & $5,3 \pm 0,4$ & $3,5 \pm 0,1$ & $5,7 \pm 0,2$ & $2,8 \pm 0,2$ & $4,7 \pm 0,6$ & - & - \\
\hline IV & $4,6 \pm 0,1$ & $8,3 \pm 0,5$ & $4,0 \pm 0,2$ & $7,5 \pm 0,2$ & 1,0 & 1,2 & - & - \\
\hline V & 3,5 & 9,0 & 1,8 & 2,0 & - & - & - & - \\
\hline
\end{tabular}

If before the start of flowering of the I order shoot, the bud laid in the axil of its 5th scale-like leaf has time to develop into a II order shoot, then this shoot continues to branch further. Otherwise, it is inhibited in development. If on the rhizome, both buds of the second order shoot renewal develop (in the axils of the 4th and 5th scale-like leaves), and both shoots bloom until the end of the growing season, then the development of the III order shoot slows down, and it does not have time to bloom before frost.

In varieties of orchid-like cannas, 2 renewal buds are laid on the shoot and both give rise to shoots. In these varieties, before frost, shoots of I-VI orders and buds of renewal of 
shoots of VI and VII orders have time to form. 4, less often 6 shoots of I-III orders bloom. The buds of the resumption of shoots of the IV-VII orders are much larger than the buds of the shoots of the I-III orders. Before frosts in the axil of the 5th scale-like leaf of the renewal bud, which forms a VI or VII order shoot, which does not have time to appear on the surface of the earth, a renewal bud is formed, giving rise to shoots when planting rhizomes the next year.

In varieties of Cannas Crozi, 7-9 assimilating leaves are formed on the I order shoot, of which the 1 st and 2 nd assimilating leaves die off before flowering. The stem bears 6-7 physiologically active assimilating leaves. In cases where the plate of the first assimilating leaf exceeds $10 \mathrm{~cm}$ in length, then one leaf less is laid on the shoot.

In all varieties, shoots that appeared in summer at high air temperatures (mean values from +26.7 to $+33.4^{\circ} \mathrm{C}$ ) grow intensively and quickly pass into the generative phase. At the same time, inhibition of bud development in the axils of the upper scaly leaves is observed on the rhizome. In autumn, with a decrease in air temperature (average ten-day temperature $+19.3^{\circ} \mathrm{C}$ and below), the growth of the aerial parts of the shoots and their transition to the generative phase slows down, but at the same time, the growth of rhizomes and the appearance of renewal buds on them is accelerated.

When studying the morphological characteristics of varieties, it was found that they differ in the height of shoots and their number, the number of leaves and flowers on the shoots, the number of renewal buds formed by the end of the growing season (Table 2).

Table 2. Morphological characteristics of cannas varieties in the Karshi oasis, $n=10$ (2017 y.)

\begin{tabular}{|c|c|c|c|c|c|c|c|c|c|c|c|c|c|}
\hline \multirow[t]{3}{*}{ Variety } & \multicolumn{3}{|c|}{$\begin{array}{l}\text { Generative shoot } \\
\text { height, } \mathrm{cm}\end{array}$} & \multicolumn{3}{|c|}{$\begin{array}{c}\text { The number of } \\
\text { leaves on the } \\
\text { shoot }\end{array}$} & \multicolumn{3}{|c|}{$\begin{array}{c}\text { The number of } \\
\text { flowers on the } \\
\text { shoot }\end{array}$} & \multicolumn{2}{|c|}{$\begin{array}{l}\text { Number of } \\
\text { shoots }\end{array}$} & \multirow{3}{*}{$\begin{array}{c}\text { The } \\
\text { numbe } \\
r \text { of } \\
\text { renewa } \\
\text { l buds } \\
\text { formed } \\
\text { by the } \\
\text { end of } \\
\text { the } \\
\text { growin } \\
g \\
\text { season }\end{array}$} & \multirow{3}{*}{$\begin{array}{c}\text { Average } \\
\text { number } \\
\text { of } \\
\text { kidney } \\
\text { per } \\
\text { shoot }\end{array}$} \\
\hline & \multicolumn{9}{|c|}{ Escapes } & \multirow[t]{2}{*}{ total } & \multirow{2}{*}{$\begin{array}{c}\text { blooming } \\
\text { before } \\
\text { frost }\end{array}$} & & \\
\hline & I & II & III & I & II & III & I & II & III & & & & \\
\hline \multicolumn{14}{|c|}{ Crozi cannas } \\
\hline $\begin{array}{c}\text { Krymskie } \\
\text { zori }\end{array}$ & $\begin{array}{l}125,6 \\
\pm 4,4 \\
\end{array}$ & $\begin{array}{c}142,8 \\
\pm 6,5 \\
\end{array}$ & - & \begin{tabular}{|c|}
7,1 \\
$\pm 0,2$ \\
\end{tabular} & \begin{tabular}{|c|}
5,7 \\
$\pm 0,1$ \\
\end{tabular} & - & $\begin{array}{l}81,1 \\
\pm 7,3 \\
\end{array}$ & \begin{tabular}{|l|}
61,8 \\
$\pm 8,9$ \\
\end{tabular} & - & $4,0 \pm 0,5$ & $2,0 \pm 0,2$ & $8,0 \pm 1,0$ & 2,0 \\
\hline America & $\begin{array}{l}110,1 \\
\pm 3,1\end{array}$ & $\begin{array}{l}156,4 \\
\pm 2,1 \\
\end{array}$ & $\begin{array}{l}157,4 \\
\pm 4,4\end{array}$ & \begin{tabular}{|c|}
8,8 \\
$\pm 0,2$ \\
\end{tabular} & \begin{tabular}{|c|}
7,7 \\
$\pm 0,2$ \\
\end{tabular} & $\begin{array}{c}6,3 \\
\pm 0,2 \\
\end{array}$ & $\begin{array}{l}21,0 \\
\pm 0,5\end{array}$ & \begin{tabular}{|l|}
30,2 \\
$\pm 2,5$
\end{tabular} & \begin{tabular}{|l}
24,8 \\
$\pm 2,8$ \\
\end{tabular} & $5,4 \pm 0,2$ & $3,1 \pm 0,1$ & $\begin{array}{c}10,5 \pm 0 \\
5\end{array}$ & 1,95 \\
\hline $\begin{array}{c}\text { Louisevon } \\
\text { Ratibor }\end{array}$ & $\begin{array}{l}115,7 \\
\pm 2,7 \\
\end{array}$ & $\begin{array}{c}154,1 \\
\pm 2,1 \\
\end{array}$ & $\begin{array}{l}173,2 \\
\pm 4,2\end{array}$ & \begin{tabular}{|c|}
6,8 \\
$\pm 0,2$ \\
\end{tabular} & \begin{tabular}{|c|}
5,4 \\
$\pm 0,2$ \\
\end{tabular} & \begin{tabular}{|c|}
5,1 \\
$\pm 0,1$ \\
\end{tabular} & \begin{tabular}{|l|}
53,3 \\
$\pm 2,7$ \\
\end{tabular} & \begin{tabular}{|l|}
67,4 \\
$\pm 7,2$ \\
\end{tabular} & \begin{tabular}{|l|}
36,3 \\
$\pm 4,2$ \\
\end{tabular} & $3,3 \pm 0,4$ & $2,3 \pm 0,2$ & $9,5 \pm 1,2$ & 2,9 \\
\hline President & $\begin{array}{l}96,2 \\
\pm 1,9\end{array}$ & $\begin{array}{c}134,7 \\
\pm 4,0\end{array}$ & $\begin{array}{l}43,3 \\
4,0\end{array}$ & $\begin{array}{c}6,7 \\
\pm 0,2\end{array}$ & $\begin{array}{c}5,7 \\
\pm 0,2\end{array}$ & $\begin{array}{c}5,1 \\
\pm 0,1\end{array}$ & \begin{tabular}{|l|}
54,8 \\
$\pm 3,7$
\end{tabular} & \begin{tabular}{|l|}
59,0 \\
$\pm 4,8$
\end{tabular} & $\begin{array}{l}43,7 \\
\pm 3,3\end{array}$ & $5,5 \pm 0,5$ & $3,1 \pm 0,6$ & $\begin{array}{c}10,5 \pm 0 \\
5\end{array}$ & 1,9 \\
\hline \multicolumn{14}{|c|}{ Canna x orchiodes } \\
\hline $\begin{array}{c}\text { Andenken } \\
\text { an } \\
\text { Wilgelm } \\
\text { Pfitzer }\end{array}$ & $\begin{array}{l}144,7 \\
\pm 6,1\end{array}$ & $\begin{array}{c}152,4 \\
\pm 4,0\end{array}$ & $\begin{array}{l}187,5 \\
\pm 7,4\end{array}$ & \begin{tabular}{|c|}
8,3 \\
$\pm 0,1$
\end{tabular} & $\begin{array}{c}6,5 \\
\pm 0,1\end{array}$ & $\begin{array}{c}5,1 \\
\pm 0,1\end{array}$ & $\begin{array}{l}25,6 \\
\pm 2,4\end{array}$ & $\begin{array}{l}26,1 \\
\pm 1,7\end{array}$ & $\begin{array}{l}37,8 \\
\pm 4,8\end{array}$ & $1,1 \pm 0,7$ & $4,4 \pm 0,3$ & $\begin{array}{c}15,7 \pm 0 \\
7\end{array}$ & 1,4 \\
\hline $\begin{array}{c}\text { Bengal } \\
\text { Tiger }\end{array}$ & $\begin{array}{l}154.5 \\
\pm 2.3\end{array}$ & $\begin{array}{c}175,0 \\
\pm 3,6\end{array}$ & $\begin{array}{c}178,7 \\
\pm 4,8\end{array}$ & \begin{tabular}{|c|}
8,5 \\
$\pm 0,1$ \\
\end{tabular} & \begin{tabular}{|c|}
7,2 \\
$\pm 0,1$
\end{tabular} & $\begin{array}{c}6,0 \\
\pm 0,1 \\
\end{array}$ & $\begin{array}{l}29,0 \\
\pm 1,1\end{array}$ & \begin{tabular}{|l|}
29,8 \\
$\pm 1,5$ \\
\end{tabular} & $\begin{array}{l}29,6 \\
\pm 1,1 \\
\end{array}$ & $1,5 \pm 0,6$ & $5,0 \pm 0,3$ & $\begin{array}{c}17,5 \pm 0 \\
4\end{array}$ & 1,5 \\
\hline $\begin{array}{l}\text { Feuer } \\
\text { Vogel }\end{array}$ & $\begin{array}{l}167,4 \\
\pm 5,0\end{array}$ & $\begin{array}{c}207,2 \\
\pm 4,6 \\
\end{array}$ & $\begin{array}{l}221,0 \\
\pm 2,3\end{array}$ & \begin{tabular}{|c|}
8,8 \\
$\pm 0,2$ \\
\end{tabular} & \begin{tabular}{|c|}
6,8 \\
$\pm 0,1$ \\
\end{tabular} & \begin{tabular}{|c|}
5,4 \\
$\pm 0,1$ \\
\end{tabular} & $\begin{array}{l}44,1 \\
\pm 4,4\end{array}$ & \begin{tabular}{|l|}
50,0 \\
$\pm 5,3$ \\
\end{tabular} & $\begin{array}{l}46,2 \\
\pm 2,8 \\
\end{array}$ & $0,3 \pm 0,6$ & $5,0 \pm 0,2$ & $\begin{array}{c}15,2 \pm 1 \\
1 \\
\end{array}$ & 1,5 \\
\hline $\begin{array}{c}\text { Rosenkran } \\
\text { zen }\end{array}$ & $\begin{array}{l}143.8 \\
\pm 3.6\end{array}$ & $\begin{array}{c}157,2 \\
\pm 5,0\end{array}$ & $\begin{array}{c}190,4 \\
\pm 1,8\end{array}$ & $\begin{array}{c}8,8 \\
\pm 0,1\end{array}$ & $\begin{array}{c}7,7 \pm \\
0,1\end{array}$ & $\begin{array}{c}5,7 \\
\pm 0,1\end{array}$ & $\begin{array}{l}35,6 \\
\pm 2,2\end{array}$ & $\begin{array}{l}46,5 \\
\pm 3,2\end{array}$ & $\begin{array}{l}32,7 \\
\pm 2,2\end{array}$ & $0,0 \pm 0,5$ & $4.1 \pm 0,3$ & $\begin{array}{c}13,9 \pm 0 \\
2\end{array}$ & 1,4 \\
\hline
\end{tabular}


As can be seen from this table, under the conditions of the Karshi oasis, in representatives of the Crozi cannas variety type, the shoot height reaches from $142.8 \pm 6.5$ (Крымские зори) to $173.2 \pm 4.5 \mathrm{~cm}$ (Louise von Ratibor), in representatives of the orchid-like cannas varieties type from $178.7 \pm 4.8$ (Bengal Tiger) to $221.0 \pm 2.3 \mathrm{~cm}$ (Feuer Vogel). On the shoots of the first order, 8-9 assimilating leaves are formed in varieties of orchid-like cannas, while in varieties of Cannas Crozi - from 6-7 (Louise von Ratibor, President) to 8-9 (America)

Cannas Crozi varieties (with the exception of the America variety) are characterized by a large number of flowers in the inflorescence of I order shoots.

In varieties of Cannas Crozi, 3-6 shoots are formed on one plant during the growing season, of which only 3-4 manage to bloom before frost. In varieties of orchid-like cannas, these indicators are much higher - 8-14 and 3-6, respectively.

Since in varieties of orchid-like cannas all the buds of renewal develop into shoots, they have only 1.4-1.5 buds of renewal per shoot, while in varieties of Crozi cannas this indicator is much higher - 1.9-2.9. But, due to the large number of shoots, the total number of renewal buds formed by the end of the growing season in varieties of orchid-like cannas is much higher than in varieties of Crozi cannas (respectively 13.9 $\pm 0.2-17.5 \pm 0.4$ and 8, 0 $\pm 1.0-10.5 \pm 0.5)$.

\section{Conclusion}

Thus, in the study of morphobiological features, it was found that Crozi cannabis varieties differ from orchid-like cannas: by a smaller number of assimilating leaves, a larger number of flowers in the inflorescence of the first order shoot, a greater activity of axillary meristems, but less activity of morphogenetic processes (the presence of dormant buds).

All varieties are characterized by:

- the influence of the size of the 1st assimilating leaf on the total number of leaves is observed only on the first order shoots;

- an increase in the height of shoots with an increase in their order;

- a decrease in the number of leaves with an increase in the order of shoots;

- in the conditions of the Karshi oasis at an elevated air temperature in June-August, there is an increased growth and development of the aboveground part, with a decrease in temperature from the end of September - the underground one.

\section{References}

1. L.N. Babushkin, Trudy SAGU, 50, 27 (1956)

2. V.E. Cub. Izmenenie klimata i ego vliyanie na gidrometeorologicheskie processy, agroklimaticheskie i vodnye resursy Respubliki Uzbekistan (Tashkent, 2007)

3. S.A. Dashkeev. Kanny v Moldavii (Stiinta, Chisinau, 1975)

4. T.I. Serebryakova. Morfogenez i ritm razvitiya vysshih rastenij (Moscow, 1987)

5. G.F. Feofilova.Trudy gos. Nikit. Bot. sada. 29, 45 (1972)

6. G.F. Feofilova., V. Yu. Dovgal'. Trudy gos. Nikit. Bot. sada.. 31, 5 (1976)

7. E.L. Nahimovskiy. Strukturnaya organizaciya i morfogenez nekotoryh semennyh rastenij: (Moscow, 1970)

8. S.V. Erushkevich. Kul'tura kann v CHujskoj doline (Frunze, Ilim, 1983)

9. Sh.A. Samatova. Vliyanie povyshennoj temperatury vozduha na razvitie kann.

Problemy i perspektivy issledovanij rastitel'nogo mira, 13-16 May, 2014, YAlta, Russia (2014) 
10. Sh.A. Samatova. Morfogenez gibridnyh kann v zavisimosti ot lokalizacii pazushnyh meristem. Cvetovodstvo: istoriya, teoriya, praktika. 24-26 May, 2016, Minsk, Belarus (2016)

11.P.K. Krasilnikov. Metodika polevogo izucheniya podzemnyh chastej rastenij.( Nauka, Leningrad, 1983)

12. V.P. Pecenitsin. Introdukciya i akklimatizaciya rastenij. (Fan. Tashket, 2003) 